Témoigner Témoigner. Entre histoire et mémoire

Getuigen Revue pluridisciplinaire de la Fondation Auschwitz

$126 \mid 2018$

Questions sur l'avenir du travail de mémoire

\title{
Het Huis van de Europese geschiedenis: een museum waar(over) vragen gesteld worden
}

La maison de l'histoire européenne : un musée qui pose (des) question(s)

\section{Christine Dupont}

Traducteur : Anneleen Spiessens

\section{(2) OpenEdition \\ Journals}

\section{Édition électronique}

URL : https://journals.openedition.org/temoigner/6930

DOI : $10.4000 /$ temoigner.6930

ISSN : 2506-6390

Cet article est une traduction de :

La maison de l'histoire européenne : un musée qui pose (des) question(s) - URL : https:// journals.openedition.org/temoigner/6885 [fr]

Éditeur :

Éditions du Centre d'études et de documentation Mémoire d'Auschwitz, Éditions Kimé

\section{Édition imprimée}

Date de publication : 2 avril 2018

Pagination : 9-12

ISBN : 978-2-930953-06-9

ISSN : 2031-4183

Référence électronique

Christine Dupont, «Het Huis van de Europese geschiedenis: een museum waar(over) vragen

gesteld worden», Témoigner. Entre histoire et mémoire [Online], 126 | 2018, Online op 24 janvier 2022, geraadpleegd op 04 février 2022. URL: http://journals.openedition.org/temoigner/6930 ; DOI: https:// doi.org/10.4000/temoigner.6930 


\section{HET HUIS VAN DE EUROPESE GESCHIEDENIS: EEN MUSEUM WAAR(OVER) VRAGEN GESTELD WORDEN}

TENTOONSTELLING 'Een museum dat meer vragen oproept dan dat ze er beantwoordt.' Dat is één van de talrijke reacties van bezoekers aan het Huis van de Europese geschiedenis sinds de opening in mei 2017. Velen vertellen ons dat ze zich verwachtten aan een Europees propagandapraatje; het museum maakt immers deel uit van het Europees parlement, de toegang is gratis. Sommigen vinden tot hun verrassing een genuanceerder en kritischer beeld. Anderen zijn ontsteld of zelfs boos over de keuzes die we maakten. Eén ding is zeker: het museum laat weinig bezoekers onberoerd.

\section{DE GESCHIEDENIS VAN EUROPA IN EEN MUSEUM}

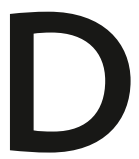

e relatieve verbazing van de bezoekers staat in verhouding met de moeilijke taak die zich stelde toen we in januari 2011 gingen nadenken over de vorm van het toekomstige museum van de Europese geschiedenis. Met 'we' bedoel ik het wetenschappelijk team van historici en curatoren. De samenwerking tussen personen afkomstig uit verschillende generaties en Europese landen was een succes omdat onze diverse methoden van onderzoek, geschiedeniscommunicatie en museumwerk complementair bleken te zijn. Die diversiteit ziet zich weerspiegeld, volgens een aantal externe commentatoren, in de manier waarop we de inhoud van ons museum presenteren.

De geschiedenis van Europa vertellen op een oppervlakte van $4000 \mathrm{~m}^{2}$, in de 24 officiële talen van de Europese Unie en op basis van originele objecten, en zonder te kunnen vertrekken vanuit een bestaande collectie: het was een bijzonder grote uitdaging. Met een wit blad beginnen biedt uiteraard ook oneindig veel creatieve mogelijkheden. Bovendien kregen we volledige wetenschappelijke vrijheid en grote budgetten van het Europees parlement, de initiatiefnemer en drager van het project. Voldoende om dit boeiende avontuur aan te vatten en op 6 mei 2017 de deuren van het museum te kunnen openen.
De enige richtlijnen die in 2008 door een comité van experten op papier waren gezet, legden niet geheel onlogisch de nadruk op de geschiedenis van de totstandkoming van Europa en op de twintigste eeuw. Verder waren we vrij om het toekomstige museum inhoudelijk vorm te geven volgens onze eigen inzichten. Het was een fascinerend werk van conceptualiseren, onderhandelen, uitschrijven, zoeken naar artefacten. Een ervaring waarvan ik kan zeggen dat ze mijn visie op Europa, en zelfs mijn verhouding tot de geschiedenis, ten gronde heeft veranderd.

\section{WAT IS EUROPA?}

Omdat er werd gekozen voor een geschiedenismuseum werkten we eerst een narratief uit. We vertrokken vanuit een selectie van processen, gebeurtenissen en concepten die volgens ons in Europa zijn ontstaan, die zich op het volledige of op een groot deel van het continent hebben ontwikkeld en waarvan de erfenis vandaag nog aanwezig is. De uiteindelijke selectie is niets meer dan de uitkomst van een reeks gesprekken van een specifiek team in een specifieke context. Een ander team, op een ander moment, had waarschijnlijke andere keuzes gemaakt. We pretenderen in geen geval dat we hiermee het ultieme verhaal van de geschiedenis van Europa hebben verteld. 
Het narratief dat de ruggengraat vormt van onze permanente tentoonstelling begint met een vraag: wat is Buses uit Fenicië die wordt ontvoerd d Europa, tier ges uit Fence stier getransfor untelijke grenzon o stelijke grenzenvan Eureit to sprekend is. Nog in het inleidende veertien elenenter cratie, de rechtsstant, de acho hrate, de rechtsstaat, de alont genwoordigheid van hetchistendon, staats copitis kapitalisme, maxisme/conmmynisme/sociali Deze thenocide.

Dezoeker vervolgens op toonstelling die na de inleiding een chronologische

volgorde aanhoudt. De geschiedenis van het Europese continent begint bij de Franse revolutie, waar de oorsprong ligt van ons modern politiek systeem, en omvat ook de Brexit. Dankzij een thematische insteek is het resultaat geen samenraapsel van nationale geschiedenissen, maar een transnationaal verhaal.

De beslissing om een 'echt' museum in te richten met originele objecten heeft uiteraard een aantal gevolgen. Ondatwe ietstarten vanitenteste collectie, habben we er zelf een samengesteld. De collectie, hebben we er zelf een samengesteld. De same merking metmecr dan 300 voomamelijk Europese musea, die ons vaak voor verschillende jaren ijke verzameling.

DE CENTRALE PLAATS VAN DE SHOAH

Het is niet de bedoeling dat dit artikel een soort van virtueel bezoek wordt aan onze permanente ten-

Galerij over de Tweede Wereldoorlog

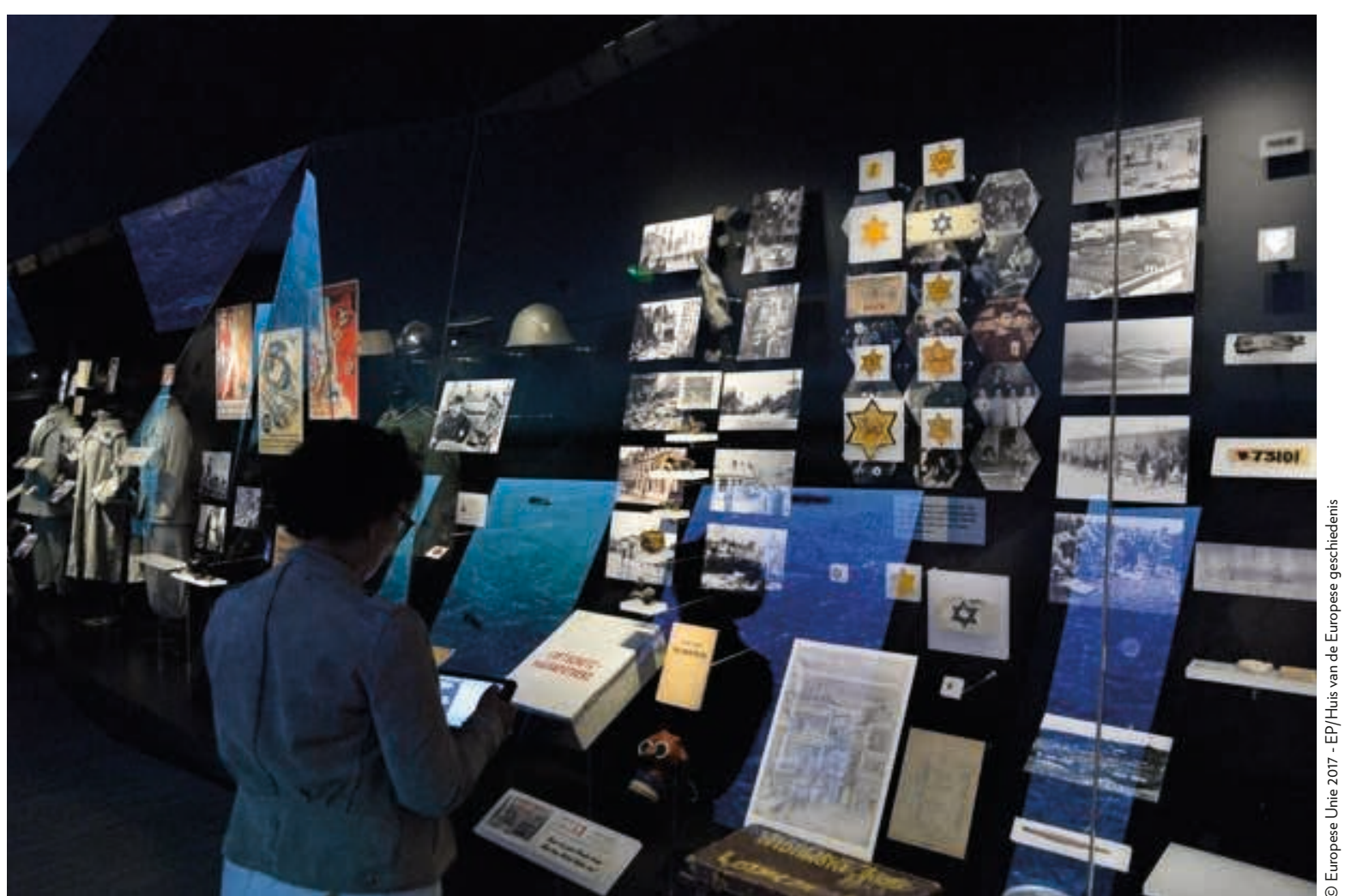

toonstelling. Daar is niet voldoende tijd voor, en het zou eentonig worden Bovendien komt een tentoon-

stelling pas echt tot haa recht in de tentoonstellingsruimte zelf, in een scenografie die daarto is ontwikkeld, met arteacten en media-opstelingen. Ik beperk me to eén voorbeeld, omda het sommige bezoe kers van streek heeft gebracht. Het gaat over de manier waarop we Shoah behandelen. Na bet persbe$\mathrm{Na}$ het persbezoek aan het museum schreef Jurek Kuczkiewicz een artikel volgende titel: 'Het volgende titel: "Het Huis van de Europese geschiedenis een museum waar, een flink 'detail" ontbreekt" (Le Soir Met zijn verwijzing Met zijn verwijzing naar de sinistere formulering van Jean-Marie Le Pen leverdehij scherpe kritie op de manier waarop we de Shoah hebben geintegreerd in het verhaal. De journalistbetreurde dater geen ruinte specifiek aan dit thema is gewijd, een keuze die als verrassen wordt aangevoeld.

Toch heeft de Shoah Toch heeft de Shoah wel degelijk een centrale plaats in de permanente genoonstelling. De pese Joden wordt al
列 in het inleidende gedeelte vermeld en er wordt daarna meermaals naa vord da na meermaals naar negentiende eeuw stellen wenteid de stellen orieën voor die in Europa orijn oor die in Europa we een kader te bieden we een kader te bieden hun ontwikkeling in de hun ontwikkeling in de extreme toepassing door het naziregime beter kan begrijpen.

De geplande vernietigingvan deEuropese Jode steld als het hoofddoel van strint regime de rentoon in ding de twee voornams dat de turen van de jaren dertis turen van de jaren dertig plaatst (zonder zerenaar op gelijke voet te stellen). Het hoofdstuk 'Genocide en massaterreure en massaterreur' preblik Zyklon B (afkom wit Zet museun van Ausuit het museum van Auscok L'Appel, een teker ook LAppel, een tekening (1927-1998) die het vreselijke (1927) dagelijks leven van een uit(uithetGhetto Fighers' Museum in Isräl) en een kopie van de plan) een kopie van de plannen voor witz-Birkenau (Yad Vashen witz-Birkenau (Yad Vashem

Devolgendegalerij bestaat voornamelijk uit een brede vitrine die de geschiedenis vanuit pantief vertelt. Het grootste dee darvan is gewijdante 
•. van de burgerbevolking (de 'totale' oorlog) overal in Europa, maar vooral in het centrum en het oosten. Thema's die hier worden aangeraakt zijn: massa-executie, deportatie, concentratiekampen en de Shoah zelf. De voorbeelden hebben vaak rechtstreeks te maken met de vervolging en uitroeiing van de Europese Joden. Ook in de verzetsverhalen komt de redding van Joden aan bod, met name in Denemarken. In de ruimte die deze donkere oorlogsperiode afsluit, 'De oogst van vernietiging', is veel aandacht voor de herinneringen van de Joodse slachtoffers van het conflict. Het dilemma van de herinnering wordt discursief weergegeven door middel van twee citaten die bewust tegenover elkaar werden geplaatst en waar veertig jaar tussen zit, namelijk dat van Winston Churchill die hoopt op een 'blessed act ofoblivion' (1946) en dat van Elie Wiesel die oproept tot herinnering om zo ‘de mensheid te redden’ (1986).

Het laatste citaat verwijst naar de herinnering aan de Shoah die we in een aparte ruimte hebben ondergebracht, in het chronologische deel 1945-1975 op de volgende verdieping. Dat is geen evidente keuze, daar zijn we ons terdege van bewust, maar we willen die graag toelichten. De verschillende ideologieën en de brutale manier waarop ze in de praktijk werden gebracht hebben we op een thematische manier willen presenteren en kaderen. Voor de Shoah hebben we het unieke karakter van de gebeurtenis willen onderstrepen door de problematische herinnering eraan te behandelen. De scenografie is sober. Achterin de zaal staat het kunstwerk van Ritula Fränkel en Nicholas Morris, De jas van Josef, waarin het koppel de herinnering bevraagt via de overjas die toebehoorde aan Ritula's vader Josef. Een reeks herinneringen van deze Shoah-overlevende zijn op de stof van de jas genaaid. Tegen de linker- en rechtermuur van de zaal bevinden zich twee grote vitrinekasten die elk drie case studies presenteren van Europese landen die hun verantwoordelijkheid in de genocide eerst hebben ontkend, en later erkend. We kozen voor de twee Duitslanden, Oostenrijk, Polen, Frankrijk en Oekraïne. Sommige zaken zijn nog steeds onderwerp van debat en tonen aan hoezeer de erkenning van deze ongeziene misdaden het hart vormt van de discussie over de Europese herinnering. Het motto van deze zaal is niet toevallig een citaat van de Britse historicus Tony Judt: 'The recovered memory of Europe's dead Jews has become the very definition and guarantee of the continent's restored humanity.'

\section{IS HET VERHAAL TE NEGATIEF?}

Sommige bezoekers verwijten ons dat we te zeer het accent hebben gelegd op het traumatische verleden van Europa. Maar die mening strookt niet met de gevarieerde permanente tentoonstelling, waarin we ons geenszins beperken tot de zwarte bladzijden uit de twintigste eeuw. Bovendien is onze eerste tijdelijke tentoonstelling gewijd aan de interactie tussen Europeanen over de grenzen en de tijden heen. We zien erop toe dat de tijdelijke tentoonstellingen complementair zijn aan de permanente, dat ze een meer culturele insteek bieden op het Europese verleden en dat ze ook andere tijdvakken belichten.

Maar het debat is niet afgesloten. Ik zou zelfs durven zeggen: het is nog maar net begonnen. Uiteraard is het geen sinecure om een museum van de Europese geschiedenis uit te denken, te realiseren en tot leven te wekken vandaag de dag. We zijn ons ervan bewust dat onze keuzes vragen kunnen oproepen, en gaan graag het gesprek aan.

Christine Dupont
(conservator van het Huis van de Europese geschiedenis)
Vertaling uit het Frans: Anneleen Spiessens

\section{Meer weten}

https://historia-europa.ep.eu

Huis van de Europese geschiedenis

Leopoldpark (Belliardstraat 135)

1000 Brussel

Gratis toegang

Open op maandag van $13.00 \mathrm{u}$ tot $18.00 \mathrm{u}$, dinsdag tot en met vrijdag van $9.00 \mathrm{u}$ tot 19.00 uur, en tijdens het weekend van $10.00 \mathrm{u}$ tot $18.00 \mathrm{u}$.

Gesloten op 1 januari, 1 mei, 1 november, 24-25-31 december.

De tentoonstelling 'Eeuwen van handel, strijd en creativiteit' loopt nog tot 31 mei 2018. 